\title{
Öğretmenlerin Kişilik Özellikleri ile Mesleki Profesyonelliği Arasındaki İlişki ${ }^{1}$
}

\author{
Ahmet Șakir YAZICI ${ }^{2}$
}

Öz

Bu çalışmanın amacı, öğretmenlerin kişilik özellikleri ile mesleki profesyonellikleri arasındaki ilişkiyi belirlemektir. Tarama modelindeki araştırmanın örneklemini, Muğla il merkezindeki okullarda görev yapan 429 öğretmen oluşturmaktadır. Veriler, Öğretmenlerin Mesleki Profesyonelliği Ölçeği ve Beş Faktör Kişilik Ölçeği ile toplanmıştır. Verilerin analizinde betimsel istatistikler, t-testi, ANOVA ve regresyon analizi kullanılmıştır. Elde edilen sonuçlara göre öğretmenlerin mesleki profesyonellik düzeyleri yüksektir. Araştırmaya katılan öğretmenlerin, başat kişilik özellikleri sırasıyla; sorumluluk, uyumluluk, zeka/hayal gücü, duygusal denge ve dişa dönüklük özellikleridir. Öğretmenlerin kişilik özellikleri ile mesleki profesyonelliği arasında pozitif ve orta düzeyde ilişkiler bulunmuştur. Regresyon analizi sonuçlarına göre kişilik özellikleri boyutlarından zeka/hayal gücü ve sorumluluk öğretmenlerin mesleki profesyonelliğinin önemli yordayıcılarıdır. Kişilik özelliklerinin tüm boyutları birlikte, öğretmenlerin profesyonelliklerinin \%31’ini açıklamaktadır.

Anahtar Kelimeler: Mesleki profesyonellik, Kişilik özellikleri, Öğretmen

\section{The Relationship between Teachers' Personality Traits and Occupational Professionalism}

\section{Abstract}

The aim of this study is to determine the relationship between teachers' personality traits and occupational professionalism. The study was designed in the survey model and the population of the study consisted of 429 teachers working at schools in the center of Mugla. The Teachers' Occupational Professionalism and Five-Factor Personality scales were used as data collection tools. Descriptive statistics, t-test, ANOVA, and regression analysis were used to analyze the data. According to the results obtained, teachers have high level of professionalism. The dominant personality traits of the participants are conscientiousness, agreeableness, and openness to experience, neuroticism, and extraversion respectively. There are moderate level of positive relationships between teachers' professionalism and personality traits. According to the results of the regression analysis, openness to experience and conscientiousness factors of personality traits are significant predictors of teachers' occupational professionalism. The dimensions of personality traits explain $31 \%$ of teachers' professionalism.

Key Words: Occupational professionalism, Personality traits, Teacher

\section{Atıf İçin / Please Cite As:}

Yazıcı, A. Ş. (2021). Öğretmenlerin kişilik özellikleri ile mesleki profesyonelliği arasındaki ilişki. Manas Sosyal Arasturmalar Dergisi, 10(4), 2107-2122.

Geliş Tarihi / Received Date: 02.04.2021

Kabul Tarihi / Accepted Date: 17.06.2021

\footnotetext{
${ }^{1}$ Bu makale 10-13 Ekim 2018 tarihleri arasında Giresun Üniversitesinde düzenlenen III. Uluslararası Felsefe, Eğitim, Sanat ve Bilim Tarihi Sempozyumu’nda sözlü bildiri olarak sunulmuş ve özeti sempozyum bildiri özet kitabında basılmış, "Öğretmenlerin Kişilik Özellikleri ile Mesleki Profesyonellikleri Arasındaki İlişki’” başlıklı bildiri geliştirilerek tamamlanmış halidir.

2 Dr. - Muğla İl Milli Eğitim Müdürlüğü Maarif Müfettişi - ahmetsakiryazici@gmail.com

iD ORCID: 0000 0002-4185-1376
} 


\section{Giriş}

Öğretmenlik mesleği zaman içerisinde entelektüel dönüşümler geçirerek profesyonel bir meslek olarak varlığını günümüzde de devam ettirmektedir. Bu durum, öğretmenlerin mesleki uygulamalarında profesyonel davranış göstermesini önemli hale getirmektedir. Her meslek gibi öğretmenlik mesleğinin de, kendine özgü özellikleri vardır. Bu özelliklerin de, aslında mesleği tanımladığı söylenebilir. Meslekler bu özellikleri değiş̧tirip geliştirdikçe profesyonelleşirler. Öğretmenlik mesleği, tarih süreci içerisinde yapılan reformlarla profesyonelleşme hareketi içerisinde bulunmuştur (Anderson, 2012). Bu durum, öğretmenlik mesleğinin, profesyonelleşmek için karakteristik özelliklerini zamanla oluşturduğunu ve okul kavramı ile birlikte geliştiğini göstermektedir. Öğretmenlerin hizmet öncesi eğitim almaları, atamalara ilişkin ölçütlerin ve süreçlerin olması, çeşitli branşlara ayrılmış olması, uygulamalarda standartlar geliştirilmiş olması, yapılan iş karşllğ̆ında para kazanılması, öğretmenliğ̈in meslekleştiğine ya da meslekleşmekte olduğuna ilişkin özellikler olarak sayllabilir. Mesleğin bu özellikleri ile beraber eğitim örgütleri, günümüzün değișen ve gelişen koşullarında gelişimini sürdürmektedir. Öğretmenlik mesleği bu gelişimini sürdürürken, yapılan işin niteliği önem kazanmaktadır. İşin niteliğini de işi yapan kişilerin içsel motivasyonu ve iç denetimi, istek ve merakları ile ilgili bir durumdur. Bu göstergeler de, kişilerin bireysel profesyonelliği olarak adlandırılabilir. Öğretmenler, mesleklerinin karakteristik özellikleri ile örgütsel profesyonelliklerini oluştururken; eğitim sürecinde gösterdikleri başarılarıyla bireysel profesyonelliklerini oluşturmaktadır. Bireysel profesyonelliğin yerini örgütsel profesyonelliğe birakması da mesleki profesyonelliği oluşturmaktadır (Evets, 2011; Altınkurt ve Yilmaz, 2014).

Mesleki profesyonellik, sistem çıktılarının niteliğinin artırılmasını esas alır (Adı̈üzel, Tanrıverdi, Sönmez ve Özkan, 2011). Bu süreçte yapısal etmenler kadar çalışanların içsel motivasyonları ve iç denetim odaklı olmaları da önemlidir (Boyt, LuschveNaylor, 2001). Çünkü kişilerin bir eylemde bulunması kendi isteklerinin sonucudur. Örneğin, iç denetim odaklı kişiler kendi yaşamlarından sorumlu olduklarını düşünerek buna uygun davranışlar ortaya koyarlar (Yılmaz ve Altınkurt, 2014, s. 333). Benzer şekilde Larson (1977, s. 29) da mesleki profesyonelliği içsel değer temelinde açılamaktadır. İçsel değer, profesyonel bir sosyalleşmedir. Profesyonellik, mesleki eylemleri yordayan ideolojik, entelektüel, davranışsal ve epistemolojik temelli bireysel bir duruş olarak tanımlanmaktadır (Evans, 2008, s. 24, 26). Bu duruş, örgüt içerisinde insanların kendi rollerini oynamasında kişisel farklılıklar yaratır (Hogan, 2019, s. 23). Çünkü kişisel farklılıklar, daha çok kişilik özelliklerinden kaynaklanmaktadır. Bu anlamda çalışanların mesleki profesyonelliği önemli hale getiren etkenlerden birisi de kişilik özellikleridir. Ancak farklı kişilik özelliğine sahip çalışanların bu özelliklerini profesyonelliklerine ne düzeyde yansıttıklarının belirlenmesi önemli bir problemdir. Bu bağlamda araştırmada, eğitim örgütlerinin çalışanı olan öğretmenlerin, kişilik özellikleri ile mesleki profesyonellikleri arasındaki ilişkinin ortaya konulması amaçlanmıştır.

Öğretmenlerin mesleki profesyonelliği, öğretmenlerin okul içi uygulamalarında, öğrenci başarısını iyileştirmek için sergiledikleri tutumlar, etkileşimler ve davranışlarla ilgili içselleştirilmiş inançlar olarak tanımlanabilir (Yılmaz ve Altınkurt, 2015). Evetts (2011) profesyonelliği, mesleki bir değer olarak açıklamaktadır. Evetts'in değerler sisteminden kastettiği, mesleki etik değerlerdir. Öğretmenlerin mesleki etik değerleri, profesyonelliğin kilit davranışlarıdır. Öğretmenler öğrencilerle ilişkilerinde, değerler üzerinden söylemlerini oluşturmaktadırlar. Bu değerler ve uygulamalar, öğretmenlerin özerkliğini oluşturur (Hargreaves, 1994, s. 434-435). Evetts (2011, s. 411) mesleki profesyonelliği etik ilkeler, iş birliği, güçlü amaç birliği, değerlendirme-karar verme, güven, değerler ve özerklik üzerinden açılamaktadır. Evans (2011), öğretmenlerin mesleki profesyonelliğini mesleki gelişim içerisinde değerlendirmektedir ve mesleki gelişimi, işlevsel gelişim ve tutum gelişimi olarak açıklamaktadır. İşlevsel gelişim, öğretmenlerin performanslarının iyileştirilmesi ve tutumsal gelişim ise öğretmenlerin işlerine yönelik tutumlarının değiştirildiği süreç olarak tanımlanmaktadır (Evans, 2011, s. 31-32). Öğretmenlerin mesleki profesyonelliklerinin niteliğinin bazı göstergeleri vardır. Bu göstergeleri Yılmaz ve Altınkurt (2015, s. 108) "alan ile ilgili bilgilere sahip olmak, alan ile ilgili değisisiklikleri takip etmek ve bu değişikliklere kolay uyum gösterebilmek; sabip olduğu bilgi, beceri ve uzmanlğ̆r kurumu yararna kullanmak; bütün bunlar yaparken tam bir profesyonel gibi davranarak etik ilkelere uygun hareket etmek ve duygularm kontrol altma alabilmek" olarak ifade etmektedirler. Bu göstergeler bağlamında mesleki profesyonelliğin boyutlarına ilişkin alanyazında farklı sinıflamalar yer almaktadır. Mesleki profesyonelliğin boyutlarını McMahon ve Hoy (2009), "akademik. sorumluluk, standartlarn öz. denetimi, etkililik ve mesleki topluluğa katke"; Yılmaz ve Altınkurt (2014) "kisisisel gelişim, mesleki duyarlhlke, kuruma katker ve duygusal emek"; Bayhan (2011) "mesleki yeterlik, profesyonel yaklassım veetkililik" ve Yazıc1 (2020) "mesleki gelisim”," "mesleki özerklik", "mesleki etik", "karara katılim sağlama"olarak belirlemiştir. Bu araştırmada öğretmenlerin mesleki profesyonelliği şu alt boyutlarda incelenmiştir:1) Kişisel 
Gelişim 2) Kuruma Katk1 3) Mesleki Duyarlılık, 4) Duygusal Emek. Yılmaz ve Altınkurt (2014) bu boyutları aşağıdaki gibi açıklamışlardır.

Kişisel Gelişim: Öğretmenlerin gönüllü olarak entelektüel bir çaba içerisinde kendilerini yetkinleştirmeleridir. Çalışanların kendilerini geliştirmek için meslekleri ile ilgili kurslara gitmeleri, mesleki kitap alıp okumaları, hizmet içi eğitim kurslarına gönüllü katılmaları, işleri ile ilgili bilimsel yayınları takip etmeleri mesleki profesyonellik davranışlarıdır.

Kuruma Katkı: Öğretmenlerin sahip olduğu entelektüel sermayesini kurum yararına kullanmasıdır. Bu anlamda entelektüel seviyesi yüksek olan öğretmenler okuldaki sosyal, kültürel ve mesleki çalışmalara, projelere gönüllü olarak katılma, çevresini okulu yararına harekete geçirmesi gibi davranışlarda bulunurlar.

Mesleki Duyarlk: Çalışanların yaptığı işi en iyi şekilde yapması için sorumluluk almalarıdır. Mesleki duyarlığ1 yüksek olan öğretmenler, kendisini değiştirip dönüştürebilen, meslektaşları ile ekip çalışması oluşturabilen, işinde titiz olan, öğrencileri ve meslektaşları ile kolayca iletişim kurabilen profesyonellerdir.

Duygusal Emek: Öğretmenlerin okulun amaçlarına uygun davranışlar gösterebilmeleri için gerçek duygularını düzenleyip yönetmesidir. Yani öğretmenlerin özel yaşamlarında ya da örgüt içi ilişkilerinde sorunlar yaşasa bile bunu işine ve ilişkilerine yansıtmamaya çalışması duygusal emek ile ilgilidir. Bu boyutlar öğretmenlerin mesleki profesyonelliğinin bir göstergesidir. Bu göstergeler uygulamaya aktarılırken, kişiler farklı eylemlerde bulunur. Bu eylemler üzerinde çalışanların kişilik özelliklerinin de etkili olduğu söylenebilir.

Kişilik, bireye özgü ve onu diğer bireylerden ayıran, tutarlı bir şekilde sergilenen özelliklerin bir bütünüdür. Bireyin kişiliğini oluşturan tüm özellikleriyle tanımak mümkün olmasa da, sürekli gösterdiği özelliklere göre çeşitli yargılarda bulunmak mümkündür. Kişilik, bireylerin kim olduğunu temsil eden özellikler toplamı olarak görülebilir (Yılmaz, 2014, s. 783). Kişiliğin özünü kişisel özellikler açılar. Ones, Viswesvaran ve Dilchert (2005) kişilik özelliklerini, insanların belirli biçimlerde düşünme, hissetme ve hareket etme gibi temel eğilimleri açısından tutarlı bir şekilde farklılaşan bir dizi bireysel özellik olarak tanımlamaktadırlar. Alanyazında kişilik özelliklerine ilişkin farklı sınıflandırmalar bulunmaktadır. Bunlardan biri, "Beş Faktör Kişilik Özellikleri”"dir. Bu modelde kişilik, temelde beş genel boyut açısından tanımlanmaktadır. Bunlar: dışa dönüklük, uyumluluk, sorumluluk, duygusal denge, zekâ/hayal gücü ve bunların karşıtı özelliklere sahip olmaktır. Bu boyutlar şöyle açıklanabilir (Somer ve Goldberg, 1999 Akt: Yilmaz, 2014, s. 783-785):

Dışa dönüklük: Heyecanl, ilişkilere önem veren, sıcakkanlı, olumlu duygusal kişiliğe sahip bireylerin özelliğidir. Dışa dönüklük özelliği düşük olan bireyler (içe dönük); sessiz, sakin, çekingen davranışlar sergilerler. Uyumluluk: Isşbirliğine inanan, samimi, anlayışlı, keyifli, arkadaşlarının iyiliğini düşünen bireylerin özelliğidir. Uyumluluk özelliği düşük olan bireyler; şüpheci, dik başlı, inatçı, sinirli davranışlar sergilerler. Sorumluluk: Başarı odaklı, güvenilir, sistemli çalışan bireylerin özelliğidir. Sorumluluk duygusu düşük olan bireyler; plansız, düzensiz, dikkatsiz davranışlar sergilerler. Duygusal dengelilik: Rahat, sabırlı, özgüvenli, eleştiriye açık bireylerin özelliğidir. Duygusal dengeliliği düşük olanlar; endişeli, gergin ve depresyonlu bireylerdir. Zekâ/hayal gücü: Bu kişilik özelliğine sahip olanlar yaratıcı fikirlere sahip, merakli, cesaretli bireylerdir. Zekâ/hayal gücü düşük olan bireyler geleneksel, tutucu, dar çerçevede düşünen bireylerdir.

Öğretmenlerin öğrenci başarısını artırmak için artı değer yaratmaları gerekmektedir. Bunun için de mesleklerinde profesyonelce davranmaları önemli hale gelmektedir. Okullarda öğretmenlerin profesyonellik davranışları farklılık gösterebilmektedir. Bu farklılık yaşamın gerçekliğine de uygundur. Çünkü her insan doğası gereği bir diğerinden farklıdır. İnsanların doğuştan getirdikleri ve sonradan edindikleri birçok özellik, onların kişiliği üzerinde etkilidir. Bu özelliklerin bilinmesi ve bu özelliklerin çalışanların iş yapma biçimlerine yansımalarının ortaya konulması örgütsel davranış alanının önemli konularından birini oluşturmaktadır.

Alanyazında, öğretmenlerin mesleki profesyonelliği ile ilgili araştırmalar bulunmaktadır. Bu araştırmalar öğretmenlerin mesleki profesyonelliği ile okul iklimi (Hoy, Hannum ve Tschannen-Moran, 1998; Hoy ve Sabo, 1998), örgütsel güven (Geist ve Hoy, 2004), okulların bürokratik yapısı (Cerit, 2012), iş doyumu (Altınkurt ve Yılmaz, 2014), tükenmişlik (Çelik ve Yılmaz 2015), okul müdürüne güven ve özyeterlik (Koşar, 2015), örgütsel sinizm düzeyleri (Altınkurt ve Ekinci, 2016), okul gelişimi (Cansoy ve Parlar, 2017) arasındaki ilişkiyi belirlemeye yöneliktir. Ayrıca okul müdürlerinin mesleki profesyonelliği ile yaşam boyu öğrenme eğilimleri (Yazıcı, 2020) arasındaki ilişkileri belirlemeye yönelik araştırma da 
bulunmaktadır. Benzer şekilde öğretmenlerin kişilik özellikleri ile bireysel farkındalık (Somer ve Goldberg, 1999), iş doyumu (Birimoğlu, 2015; Demirci, 2003; Deniz, 2008; Göl ve Y1ldırım, 2015; Koca, 2016), ögretmenlik mesleğine yönelik tutum (Şenel, Demir, Sertelin, Kılıçaslan ve Köksal, 2004), farkındalık yaratma ve yanlış anlamayı düzeltme (Ones, Viswesvaranve Dilchert, 2005), duygusal taciz (Girgin, 2007), örgütsel vatandaşlık (Göksal, 2007), öğretmen yeterlikleri (Kalafat, 2012), karar verme becerileri (Ercan, 2014), tükenmişlik (Yilmaz, 2014), örgütsel sinizm (Sargin, 2016), okul iklimi (Sayg1l, 2016) arasındaki ilişkileri belirlemeye yönelik araştırmalar da bulunmaktadır. Ancak, alanyazında eğitim alanında profesyonellik ile kişilik özellikleri ilişkisini ele alan bir çalışmaya ulaşılamamıştır. Dolayısıyla bu araştırmanın sonuçlarının, ögretmenlerin profesyonel gelişimine katkı sağlayacağı, meslektaşları ve okul yöneticileri ile ilişkilerini düzenleme konusunda farkındalık yaratacağı, sahip oldukları özellikleri okulun amaçları doğrultusunda en etkili biçimde kullanmalarına katkı sağlayacağı düşünülmektedir.

Bu çalışmanın amacı, öğretmenlerin kişilik özellikleri ile mesleki profesyonellikleri arasındaki ilişkinin belirlenmesidir. Bu genel amaç çerçevesinde araştırmada aşağıdaki sorulara yanıt aranmıştır:

1. Öğretmenlerin mesleki profesyonellikleri ne düzeydedir?

2. Öğretmenlerin, başat kişilik özellikleri nelerdir?

3. Öğretmenlerin mesleki profesyonellikleri cinsiyet, okul türü, okul kademesi, branşa ve kıdeme; kişilik özellikleri cinsiyete göre istatistiksel olarak anlamlı düzeyde farkllık göstermekte midir?

4. Öğretmenlerin kişilik özellikleri, mesleki profesyonelliklerini anlamlı düzeyde yordamakta mıdır?

\section{Yöntem}

Araştırma tarama modelinde desenlenmiştir. Çünkü araştırmada, öğretmenlerin kişilik özellikleri ve mesleki profesyonellik düzeyleri var olan durumu ile betimlenmeye çalş̧1lmıştır.

\section{Evren - Örneklem}

Araştırmanın evrenini, 2017-2018 öğretim yilında Muğla il ve ilçe merkezlerinde bulunan, toplam 778 devlet ve özel okullarında görev yapan 12.181 öğretmen oluşturmaktadır. Araştırmanın örnekleminin belirlenmesinde oransız küme örnekleme tekniği kullanılmıştır. Örneklem büyüklüğü .95 güven düzeyinde 372 öğretmen olarak hesaplanmıştır. Ölçeklerin geri dönüşünde eksiklikler ve özensiz doldurmalar olabileceği göz önünde bulundurularak, 471 öğretmenden veri toplanmıştır. Toplanan ölçeklerden 42'sieksik ve özensiz doldurulması nedeniyle analize dâhil edilmemiştir. Ayrıca kullanılacak istatistiklerin varsayımını sağlamak için normallik analizleri yapılmıştır. Bu çerçevede 25 ölçek tek ve çok değişkenli normallik varsayımını karşılamadığı için değerlendirilmeye alınmamıştır. Böylece kullanılabilir durumda olan 404 ölçek analize dâhil edilmiştir.

Araştırmaya katılan öğretmenlerin \%90.3'ü devlet okullarında, \%9.7’si özel okullarda; \%40.6’i ilkokul $(n=164), \% 34.9$ 'u ortaokul ( $n=141), \% 10.1$ 'i liselerde $(n=41)$ ve \%14.4'ü ( $n=58)$ meslek liselerinde görev yapmaktadır. Katılımcıların \%36.4'ü sınıf öğretmeni ( $\mathrm{n}=147), \% 49.8$ ’ $\mathrm{i}$ branş öğretmeni $(\mathrm{n}=201)$ ve \%13.9'u meslek dersi öğretmenidir ( $\mathrm{n}=56$ ). Araştırmaya katılan öğretmenlerin \%58.9'u kadın ( $\mathrm{n}=238$ ), \%41.1'i erkektir ( $\mathrm{n}=166)$. Araştırmaya katılan öğretmenlerin hizmet süreleri 1 ile 42 yıl arasında değişmektedir. Hizmet süresi 10 yilın altında olanların oranı \%37.6 ( $\mathrm{n}=152), 11-20$ arasında olanların oranı $\% 35.9(\mathrm{n}=145), 21$ yıl ve üzerinde olanların oranı $\% 26.5$ tir $(\mathrm{n}=107)$.

\section{Veri Toplama Araçları}

Araştırmada veri toplama aracı olarak, Öğretmenlerin Mesleki Profesyonellik Ölçeği ve Kişilik Özellikleri Ölçeği kullanılmıştır. Öğretmenlerin Mesleki Profesyonelliği Ölçeği, Yılmaz ve Altınkurt (2014) tarafından geliştirilmiştir. Likert tipi 24 maddeden oluşan ölçek, kişisel gelişim, kuruma katkı, mesleki duyarlılık ve duygusal emek boyutlarından oluşmaktadır. Söz konusu dört faktörlü yapı, toplam varyansın $\% 52.2$ 'sini açıklamaktadır. Ölçeğin boyutlarındaki maddelerinin faktör yük değerleri .40 ile .84, madde-toplam korelasyonları .35 ile .73 arasında değişmektedir. Ölçeğin doğrulayıcı faktör analizi (DFA) ile elde edilen uyum iyiliği indeksleri şöyledir: $\chi^{2} / \mathrm{sd}=2.66 \mathrm{GFI}=.82$, AGFI $=.78, \mathrm{RMSEA}=.08, \mathrm{RMR}=.05$, $\mathrm{SRMR}=.08, \mathrm{CFI}=.80, \mathrm{NFI}=.72$, NNFI=.77, PGFI=.67. Ölçeğin Cronbach Alfa iç tutarlllık katsayıları, kişisel gelişim boyutu için .79, mesleki duyarlılık boyutu için .74, kuruma katkı boyutu için .86, duygusal emek boyutu için .80 ve ölçeğin tümü için .90 olarak hesaplanmıştır. Ölçeğin bu araştırmadaki Cronbach Alfa iç tutarlılık katsayıları, kişisel gelişim boyutu için .70, mesleki duyarlılık boyutu için .71, kuruma katk1 boyutu için .80 , duygusal emek boyutu için .82 ve ölçeğin tümü için .87 olarak hesaplanmıştır. Ölçekte yer 
alan maddeler, 1-kesinlikle katılmıyorum ile 5-kesinlikle katıllyorum" aralığında puanlanmaktadır. Ölçekten alınan puanın yükselmesi yanıllayan kişinin mesleki profesyonellik düzeyinin yüksekliğine işaret etmektedir.

Goldberg (1992) tarafından geliştirilen Beş Faktör Kişilik Ölçeği, Tatar (2017) tarafından Türkçeye uyarlanmıştır. Likert tipi 50 maddeden oluşan ölçek, dişa dönüklük, uyumluluk, sorumluluk, duygusal denge ve zekâ/hayal gücü boyutlarından oluşmaktadır. Ölçekte yer alan maddeler, 1-hiç uygun değil ile 5çok uygun" aralığında puanlanmaktadır. Tatar (2017), faktörlerinin asıl uygulamada .65 ile .79 arasında, tekrar test uygulamasında .67 ile .81 arasında iç tutarllılık gösterdiğini belirtmiştir. Ölçekte ters puanlanmış maddeler bulunmaktadır. Ölçekten alınan puanın yüksek ya da düşük olması yanıtlayan kişinin o iki farklı uçtaki kişilik özelliğinden birine sahip olduğu anlamına gelmektedir. Örneğin, dışa dönüklük puanının yüksek olması katılımcıların dışa dönük, düşük olması ise içe dönük kişilik özelliği gösterdiği anlamına gelmektedir. Ölçeğin bu araştırmadaki Cronbach Alfa iç tutarlılık katsayıları, dışa dönüklük boyutu için .70, uyumluluk boyutu için .73, sorumluluk boyutu için .75, duygusal denge boyutu için .77, zeka/hayal gücü boyutu için .64 ve ölçeğin tümü için .88 olarak hesaplanmıştır.

\section{Verilerin Analizi}

Araştırmada, verilerin analizine geçilmeden önce kullanılan istatistiklerin varsayımları kontrol edilmiştir. Bu amaçla öncelikle tek ve çok yönlü uç değer analizi yapılmıştır. Bu çerçevede $z$ değerlerine ( $\mathrm{z}$ Z 3) bakılmış ve 19 ölçek analiz dışı bırakılmıştır. Kalan 410 ölçekten 6'sı ise Mahalanobis Uzaklığına bakılarak analiz dışında kalmıştır. Ardından çoklu bağlantı problemi olup olmadığına da Varyans Büyütme Faktörü-VIF (Variance Inflation Factor) incelenerek karar verilmiştir. Yapılan analizler sonucunda VIF değerlerinin hiçbirinin 10'dan büyük olmadığı (en yüksek VIF değeri = 1,64) yani çoklu bağlantı sorunu olmadığı görülmüş̧tür.

Araştırmada öğretmenlerin, kişilik özellikleri ile mesleki profesyonellik görüşlerini belirlemek amacıyla betimsel istatistikler, ikili karşılaştırmalarda t-testi, üç ve daha fazla boyutu olan karşılaştırmalarda tek yönlü varyans analizi (ANOVA) kullanılmıştır. Anlamlı çıkan F değerleri için, farkın kaynağını belirlemek üzere çoklu karşılaştırma testlerinden Sidak testi kullanılmıştır. Araştırmada öğretmenlerin kişilik özellikleri ile mesleki profesyonellikleri davranışları arasındaki ilişkinin belirlenmesi için ise Pearson korelasyon analizi kullanılmıştır. Korelasyon katsayısının mutlak değer olarak, .70-1.00 arasında olması yüksek; .69-.30 arasında olması orta; .29'dan küçük olması ise düşük düzeyde ilişki olarak yorumlanmışır (Büyüköztürk, 2015). Ayrıca öğretmenlerin kişilik özelikleri davranışlarının alt boyutlarının, mesleki profesyonelliği yordamasına ilişkin regresyon analizi yapılmışır.

\section{Bulgular}

Araştırmaya katılan öğretmenlerin, başat kişilik özellikleri sırasıyla, sorumluluk ( $\mathrm{AO}=4.17, \mathrm{~S}=.54)$, uyumluluk $(\mathrm{AO}=4.03, \mathrm{~S}=.52)$, zekâ/hayal gücü $(\mathrm{AO}=3.79, \mathrm{~S}=.47)$, duygusal denge $(\mathrm{AO}=3.35, \mathrm{~S}=.64)$ ve dişa dönüklüktür $(\mathrm{AO}=3.14, \mathrm{~S}=.57)$.

Cinsiyet değişkenine göre öğretmenlerin, dişa dönüklük $\left[\mathrm{t}_{(402)}=.87, \mathrm{p}>.05\right]$, duygusal denge $\left[\mathrm{t}_{(402)}=1.92\right.$, $\mathrm{p}>$.05], zekâ/hayal gücü $\left[\mathrm{t}_{(402)}=.61, \mathrm{p}>.05\right]$ kişilik özellikleri anlamlı düzeyde farklılaşmamaktadır. Ancak öğretmenlerin uyumluluk [ $\left.\mathrm{t}_{(402)}=3.96, \mathrm{p}<.05\right]$ ve sorumluluk $\left[\mathrm{t}_{(402)}=2.89, \mathrm{p}<.05\right]$ kişilik özellikleri cinsiyete göre farklılaşmaktadır. Kadın öğretmenlerin hem uyumluluk $(\mathrm{AO}=4.12, \mathrm{~S}=.50)$ hem de sorumluluk puanları $(\mathrm{AO}=4.24, \mathrm{~S}=.54)$, erkek öğretmenlerin uyumluluk $(\mathrm{AO}=3.92, \mathrm{~S}=.54)$ ve sorumluluk $(\mathrm{AO}=4.08$, $\mathrm{S}=.52)$ puanlarından daha yüksektir.

Araştırmaya katılan öğretmenlerin genel mesleki profesyonellik düzeyleri $(\mathrm{AO}=4.15, \mathrm{~S}=.40)$ yüksektir. Öğretmenlerin mesleki profesyonellik düzeyleri sırası ile mesleki duyarllık ( $\mathrm{AO}=4.56, \mathrm{~S}=.43)$, duygusal emek ( $\mathrm{AO}=4.52, \mathrm{~S}=.47)$, kuruma katk1 $(\mathrm{AO}=3.92, \mathrm{~S}=.57)$ ve kişisel gelişimdir $(\mathrm{AO}=3.68, \mathrm{~S}=.62)$.

Cinsiyet değişkenine göre öğretmenlerin genel mesleki profesyonellik düzeyleri $\left[\mathrm{t}_{(402)}=1.45, \mathrm{p}>.05\right]$ ile mesleki profesyonelliğin boyutlarından kişisel gelişim $\left[\mathrm{t}_{(402)}=.062, \mathrm{p}>.05\right]$ ve kuruma katk1 $\left[\mathrm{t}_{(402)}=.89\right.$, p>.05] düzeyleri anlamlı düzeyde farklılaşmamaktadır. Ancak öğretmenlerin mesleki duyarllık düzeyleri $\left[\mathrm{t}_{(402)}=4.26, \mathrm{p}<.05\right]$ ve duygusal emek düzeyleri $\left[\mathrm{t}_{(402)}=3.26, \mathrm{p}<.05\right]$ cinsiyete göre farklılaşmaktadır. Kadın öğretmenlerin hem mesleki duyarll11k $(\mathrm{AO}=4.64, \mathrm{~S}=.40)$ hem de duygusal emek puanları $(\mathrm{AO}=4.59$, $\mathrm{S}=.44)$, erkek öğretmenlerin mesleki duyarllık $(\mathrm{AO}=4.46, \mathrm{~S}=.44)$ ve duygusal emek puanlarından $(\mathrm{AO}=4.43, \mathrm{~S}=.49)$ daha yüksektir. Bu bulgu, kadın öğretmenlerin duygusal emek ve mesleki duyarlık düzeylerinin erkek öğretmenlerin duygusal emek ve mesleki duyarlllık düzeylerinden daha yüksek olduğunu göstermektedir. 
Okul türü değişkenine göre öğretmenlerin genel mesleki profesyonellik $\left[\mathrm{t}_{(402)}=1.88, \mathrm{p}>.05\right]$ ile mesleki profesyonelliğin boyutlarından kişisel gelişim $\left[\mathrm{t}_{(402)}=1.35, \mathrm{p}>.05\right]$, kuruma katk1 $\left[\mathrm{t}_{(402)}=1.69, \mathrm{p}>.05\right]$, mesleki duyarlik [ $\left.\mathrm{t}_{(402)}=1.75, \mathrm{p}>.05\right]$ ve duygusal emek [ $\left.\mathrm{t}_{(402)}=.86, \mathrm{p}>.05\right]$ düzeyleri devlet okulu ve özel okul ögretmenleri arasında anlamlı düzeyde farklılaşmamaktadır.

Okul kademesi değişkenine göre öğretmenlerin genel mesleki profesyonellik $\left[\mathrm{F}_{(3-400)}=5.65 ; \mathrm{p}<.05\right]$ ile mesleki profesyonelliğin kuruma katk1 $\left[\mathrm{F}_{(3-400)}=12.12 ; \mathrm{p}<.05\right]$ ve duygusal emek $\left[\mathrm{F}_{(3-400)}=5.09 ; \mathrm{p}<.05\right]$ düzeyleri anlamlı düzeyde farklılaşmaktadır. Ancak mesleki duyarlılık $\left[\mathrm{F}_{(3-400)}=2.57 ; \mathrm{p}>.05\right]$ ve kişisel gelişimleri $\left[\mathrm{F}_{(3-400)}=.19 ; \mathrm{p}>.05\right]$ farklılaşmamaktadır. Genel mesleki profesyonellik düzeyleri arasındaki farklılık, ilkokul öğretmenleri $(\mathrm{AO}=4.25, \mathrm{~S}=.36)$ ile ortaokul $(\mathrm{AO}=4.09, \mathrm{~S}=.41)$ ve lise öğretmenleri $(\mathrm{AO}=4.04, \mathrm{~S}=.38)$ arasındadır. İlkokul öğretmenlerinin genel mesleki profesyonellik düzeyleri, ortaokul ve lise öğretmenlerinden daha yüksektir. Mesleki profesyonelliğin kuruma katkı boyutunda farklılık ilkokul öğretmenleri $(\mathrm{AO}=4.08, \mathrm{~S}=.51)$ ile ortaokul $(\mathrm{AO}=3.75, \mathrm{~S}=.59)$ ve lise öğretmenleri $(\mathrm{AO}=3.70, \mathrm{~S}=.57)$ arasında; yine ortaokul öğretmenleri $(\mathrm{AO}=3.75, \mathrm{~S}=.59)$ ile meslek lisesi öğretmenleri $(\mathrm{AO}=4.02, \mathrm{~S}=0.54$ arasındadır. Duygusal emek boyutunda ise fark, ilkokul öğretmenleri $(\mathrm{AO}=4.63, \mathrm{~S}=.43)$ ile ortaokul $(\mathrm{AO}=4.47, \mathrm{~S}=.46)$ ve meslek lisesi $(\mathrm{AO}=4.42, \mathrm{~S}=.53)$ öğretmenleri arasındadır. Mesleki profesyonelliğin kuruma katkı boyutunda ilkokul öğretmenlerinin kuruma katk1 puanı ortaokul ve lise öğretmenlerinden daha yüksek, ortaokul öğretmenlerinin de meslek lisesi öğretmenlerinden daha yüksektir. Mesleki profesyonelliğin duygusal emek boyutunda ise ilkokul öğretmenlerinin puanları ortaokul ve meslek lisesi öğretmenlerinden daha yüksektir.

Kıdem değişkenine göre ise öğretmenlerin mesleki profesyonellik düzeyleri genel mesleki profesyonellik, kuruma katkı ve duygusal emek boyutlarında anlamlı düzeyde farklılaşmaktadır. Farklılık genel mesleki profesyonellikte $\left[\mathrm{F}_{(2-401)}=6.08 ; \mathrm{p}<.05\right], 21$ y1 ve üzerinde $(\mathrm{AO}=4.27, \mathrm{~S}=.32)$ k1deme sahip öğretmenler ile 10 y1l ve altunda $(\mathrm{AO}=4.11, \mathrm{~S}=.42)$ ve11-20 y1l arası kıdemi olan öğretmenler $(\mathrm{AO}=4.11$, $\mathrm{S}=.41)$ arasındadır. Kuruma katk1 boyutundaki farklılık $\left[\mathrm{F}_{(2-401)}=11.24 ; \mathrm{p}<.05\right], 21$ y1l ve üzeri k1deme sahip olan $(\mathrm{AO}=4.13, \mathrm{~S}=.50)$ ögretmenler ile $10 \mathrm{y} 1 \mathrm{l}$ ve altında $(\mathrm{AO}=3.80, \mathrm{~S}=.59)$ ve $11-20$ y1l aras1 kıdeme sahip ögrretmenler ( $\mathrm{AO}=3.88, \mathrm{~S}=.56)$ arasındadır. Duygusal emek boyutundaki farklilık $\left[\mathrm{F}_{(2-401)}=6.72 ; \mathrm{p}<.05\right], 21$ y1l ve üzerinde $(\mathrm{AO}=4.66, \mathrm{~S}=.38)$ kıdeme sahip öğretmenler ile 10 yll ve altında $(\mathrm{AO}=4.47, \mathrm{~S}=.48)$ ve 11 20 y1l arası kıdeme sahip olan öğretmenler arasındadır. 21 y1l ve üzeri olan öğretmenlerin genel mesleki profesyonellikleri, kuruma katkıları ve duygusal emekleri20 yıl ve altında kıdeme sahip öğretmenlerden daha yüksektir.

Öğretmenlerin kişilik özelliklerinin mesleki profesyonellik düzeylerini ne düzeyde yordadığını belirlemek amacı ile yapılan regresyon analizi sonuçları aşağıdaki tablolarda yer almaktadır. Tablo 1'de öğretmenlerin kişilik özelliklerinin, mesleki profesyonelliğin kişisel gelişim düzeylerini yordayıp yormadığının belirlenmesi amacı ile yapılan çoklu regresyon analizi sonuçlarına yer verilmiştir.

Tablo 1. Kişisel Gelişim Düzeyinin Yordanmasina İlişkin Regresyon Analiz̨i Sonuçlar

\begin{tabular}{|c|c|c|c|c|c|c|c|}
\hline Değişken & $B$ & Standart Hata & $\beta$ & $t$ & $p$ & $\begin{array}{c}\dot{I}_{k i l i} \\
\boldsymbol{r}\end{array}$ & $\begin{array}{c}\text { Kismi } \\
r\end{array}$ \\
\hline Sabit & 1.70 & .28 & - & 6.04 & .00 & - & - \\
\hline 1. Dişa dönüklük & .09 & .06 & .08 & 1.47 & .14 & .21 & .07 \\
\hline 2. Uyumluluk & -.17 & .07 & -.14 & 2.43 & .02 & .14 & -.12 \\
\hline 3. Sorumluluk & .25 & .07 & .21 & 3.65 & .00 & .30 & .18 \\
\hline 4. Duygusal denge & -.01 & .05 & -.01 & .16 & .88 & .13 & -.01 \\
\hline 5. Zekâ/hayal gücü & .36 & .07 & .27 & 4.80 & .00 & .35 & .23 \\
\hline $\mathrm{R}=.39 \quad \mathrm{R}^{2}=.16$ & & & $\mathrm{~F}_{(5-398)}=$ & $2 \mathrm{p}=$ & & & \\
\hline
\end{tabular}

Tablo 1'e göre, kişisel gelişim ile kişilik özelliklerinin sorumluluk $(\mathrm{r}=.30)$ ve zekâ/hayal gücü $(\mathrm{r}=.35)$ boyutları arasında pozitif ve orta düzeyde ilişki, dışa dönüklük $(r=.21)$, uyumluluk( $r=.14)$ ve duygusal denge $(\mathrm{r}=.13)$ arasında ise pozitif ve düşük düzeyde ilişki bulunmuştur. Diğer değişkenler kontrol edildiğinde ise zekâ/hayal gücü ile kişisel gelişim $(r=.23)$ arasında pozitif ve orta düzeye yakın bir ilişki; sorumluluk değişkeni ( $\mathrm{r}=.18)$ ile pozitif ve düşük düzeyde, uyumluluk değişkeni ile negatif ve düşük düzeyde bir ilişki belirlenmiştir. Kişilik özelliklerinin boyutları tümü birlikte, öğretmenlerin kişisel gelişim düzeyleri ile orta düzeyde ve anlamlı bir ilişki vermektedir $(\mathrm{R}=.40, \mathrm{p}<.01)$. Standardize edilmiş regresyon katsayısına $(\beta)$ göre yordayıcı değişkenlerin öğretmenlerin kişisel gelişim düzeyleri üzerindeki göreli önem sırası; zekâ/hayal gücü, sorumluluk, uyumluluk, dişa dönüklük ve duygusal dengedir. Regresyon 
katsayılarının anlamlılığına ilişkin t-testi sonuçları incelendiğinde zekâ/hayal gücü, sorumluluk ve uyumluluk kişilik özellikleri öğretmenlerin kişisel gelişiminin önemli yordayıcısıdır. Kişilik özelliklerinin boyutları tümü birlikte, öğretmenlerin kişisel gelişim düzeylerinin \%16'sını açıklamaktadır. Elde edilen bulgulara göre kişisel gelişimin regresyon eşitliği şöyledir:

\section{Kişisel Gelişim $=1.70+.09$ Dışa dönüklük - .17 Uyumluluk +.25 Sorumluluk - .01 Duygusal denge + .36 Zekal hayal gücü}

Regresyon eşitliğinde de görüldüğü gibi öğretmenlerin zeka/hayal gücü, sorumluluk ve uyumluluk kişilik özelliği arttıkça kişisel gelişim davranışları da önemli düzeyde artmaktadır. Ancak dışa dönüklük ve duygusal denge kişilik özelliklerinin öğretmenlerin kişisel gelişim üzerinde kayda değer bir etkisi bulunmamaktadır.

Tablo 2'de öğretmenlerin kişilik özelliklerinin, mesleki duyarlık düzeylerini yordayıp yordamadığının belirlenmesi amacı ile yapılan çoklu regresyon analizi sonuçlarına yer verilmiştir.

Tablo 2. Mesleki Duyarlk Düreyinin Yordanmasma İliskin Regresyon Analizi Sonuclar

\begin{tabular}{|c|c|c|c|c|c|c|c|}
\hline Değişken & $B$ & Standart Hata & $\beta$ & $\bar{t}$ & $p$ & $\begin{array}{c}\dot{I} k i l i \\
r\end{array}$ & $\begin{array}{c}\text { Kismi } \\
r\end{array}$ \\
\hline Sabit & 2.71 & .19 & - & 14.50 & .00 & - & - \\
\hline 1. Dişa dönüklük & -.02 & .04 & -.02 & -.44 & .66 & .20 & -.02 \\
\hline 2. $\quad$ Uyumluluk & .11 & .05 & .14 & 2.51 & .01 & .35 & .13 \\
\hline 3. Sorumluluk & .12 & .05 & .15 & 2.62 & .01 & .36 & .13 \\
\hline 4. $\quad$ Duygusal denge & .04 & .03 & .01 & 1.28 & .20 & .18 & .06 \\
\hline 5. Zekâ/hayal gücü & .22 & .05 & .24 & 4.33 & .00 & .40 & .21 \\
\hline $\mathrm{R}=.46 \quad \mathrm{R}^{2}=.21$ & & & $\mathrm{~F}_{(5-398)}=$ & $89 \mathrm{p}=$ & & & \\
\hline
\end{tabular}

Tablo 2'ye göre, mesleki duyarlık ile kişilik özelliklerinin sorumluluk ( $\mathrm{r}=0.36)$, zekâ/hayal gücü $(\mathrm{r}=.40)$, uyumluluk $(\mathrm{r}=.35)$, dışa dönüklük ( $\mathrm{r}=.20)$ boyutları arasında pozitif ve orta düzeyde ilişki; duygusal denge $(r=0.18)$ arasında ise pozitif ancak düşük düzeyde ilişki bulunmuştur. Diğer değişkenler kontrol edildiğinde ise zekâ/hayal gücü ile mesleki duyarlık $(\mathrm{r}=.21)$, sorumluluk $(\mathrm{r}=.13)$ ve uyumluluk $(\mathrm{r}=.13)$ değişkeni ile pozitif ve düşük düzeyde ilişkiler bulunmuş; ancak dişa dönüklük ve duygusal denge $(\mathrm{r}=.06)$ değişkenleri ile istatistiksel olarak anlamlı bir ilişki bulunmamaktadır. Kişilik özelliklerinin boyutları tümü birlikte, öğretmenlerin mesleki duyarlık düzeyleri ile orta düzeyde ve anlamlı bir ilişki vermektedir $(\mathrm{R}=.46$, $\mathrm{p}<.01)$. Standardize edilmiş regresyon katsayısına $(\beta)$ göre yordayıcı değişkenlerin öğretmenlerin mesleki duyarlık düzeyleri üzerindeki göreli önem sırası; zekâ/hayal gücü, sorumluluk, uyumluluk, duygusal denge ve dışa dönüklüktür. Regresyon katsayılarının anlamlılı̆ına ilişkin t-testi sonuçları incelendiğinde zekâ/hayal gücü, sorumluluk ve uyumluluk öğretmenlerin mesleki duyarlılığın önemli yordayıcısıdır. Kişilik özelliklerinin boyutları tümü birlikte, öğretmenlerin mesleki duyarlık düzeylerinin \%21'ini açıllamaktadır. Elde edilen bulgulara göre mesleki duyarllığın regresyon eşitliği şöyledir:

\section{Mesleki duyarlllk $=2.71-.02$ Dışa dönüklük +.11 Uyumluluk +.12 Sorumluluk +.04 Duygusal denge+ .22 Zekâl hayal gücü}

Regresyon eşitliğinde de görüldüğü gibi öğretmenlerin zekâ/hayal gücü, sorumluluk ve uyumluluk kişilik özelliği arttıkça mesleki duyarlılık davranışları da önemli düzeyde artmaktadır. Ancak dışa dönüklük ve duygusal denge kişilik özelliklerinin öğretmenlerin mesleki duyarlılık davranışları üzerinde kayda değer bir etkisi bulunmamaktadır.

Tablo 3'de öğretmenlerin kişilik özelliklerinin, kuruma katkı düzeylerini yordayıp yordamadığının belirlenmesi amacı ile yapılan çoklu regresyon analizi sonuçlarına yer verilmiştir. 
Tablo 3.b Kuruma Katkı Düzeyinin Yordanmasına Ilişkin Regresyon Analiz̧i Sonuçlar

\begin{tabular}{|c|c|c|c|c|c|c|c|}
\hline Değişken & $B$ & Standart Hata & $\beta$ & $t$ & $p$ & $\begin{array}{c}\dot{I} k i l i \\
t\end{array}$ & $\begin{array}{c}\text { Kismi } \\
r\end{array}$ \\
\hline Sabit & 1.56 & .25 & - & 6.18 & .00 & - & - \\
\hline Dişa dönüklük & .12 & .06 & .125 & 2.25 & .03 & .29 & .11 \\
\hline Uyumluluk & .05 & .06 & .05 & .87 & .39 & .29 & .04 \\
\hline Sorumluluk & .19 & .06 & .18 & 3.10 & .00 & .35 & .15 \\
\hline Duygusal denge & .03 & .05 & .04 & .74 & .46 & .20 & .04 \\
\hline Zekâ/hayal gücü & .23 & .07 & .12 & 3.34 & .00 & .37 & .17 \\
\hline $\mathrm{R}=.44 \quad \mathrm{R}^{2}=.19$ & & & $F_{(5-398)}=1$ & $\mathrm{p}=$. & & & \\
\hline
\end{tabular}

Tablo 3'e göre, kuruma katk1 ile kişilik özelliklerinin sorumluluk ( $\mathrm{r}=.35)$, zekâ/hayal gücü $(\mathrm{r}=.37)$, uyumluluk ( $\mathrm{r}=.29)$, dışa dönüklük ( $\mathrm{r}=.29)$ boyutları arasında pozitif ve orta düzeyde ilişki; duygusal denge $(\mathrm{r}=.20)$ boyutu arasında ise pozitif ancak düşük düzeyde ilişki bulunmuştur. Diğer değişkenler kontrol edildiğinde ise zekâ/hayal gücü $(\mathrm{r}=.17)$, sorumluluk $(\mathrm{r}=.15)$, dışa dönüklük $(\mathrm{r}=.11)$ ile kuruma katk1 arasında pozitif ve düşük düzeyde bir ilişki; ancak uyumluluk $(\mathrm{r}=.04)$, duygusal denge $(\mathrm{r}=.04)$ değişkenleri ile istatistiksel olarak anlamlı bir ilişki bulunmamaktadır. Kişilik özelliklerinin boyutları tümü birlikte, öğretmenlerin kuruma katkı düzeyleri ile orta düzeyde ve anlamlı bir ilişki vermektedir $(\mathrm{R}=.44, \mathrm{p}<.01)$. Standardize edilmiş regresyon katsayısına $(\beta)$ göre yordayıcı değişkenlerin öğretmenlerin kuruma katkı düzeyleri üzerindeki göreli önem sırasi; zekâ/hayal gücü, sorumluluk, dışa dönüklük, uyumluluk ve duygusal dengedir. Regresyon katsayılarının anlamlllığına ilişkin t-testi sonuçları incelendiğinde; zekâ/hayal gücü, sorumluluk ve dışa dönüklük kişilik özellikleri öğretmenlerin kuruma katkısının önemli yordayıcısıdırlar. Kişilik özelliklerinin boyutları tümü birlikte, öğretmenlerin kuruma katkı düzeylerinin \% 19’unu açıklamaktadır. Elde edilen bulgulara göre kuruma katkının regresyon eşitliği şöyledir:

\section{Kuruma katkı $=1.56+.12$ Dışa dönüklük +.05 Uyumluluk +.19 Sorumluluk +.03 Duygusal denge + .23 Zekâa/ bayal gücü}

Regresyon eşitliğinde de görüldüğü gibi öğretmenlerin zeka/hayal gücü, sorumluluk ve dişa dönüklük kişilik özelliği arttıkça kuruma katkı davranışları da önemli düzeyde artmaktadır. Ancak uyumluluk ve duygusal denge kişilik özelliklerinin öğretmenlerin kuruma katkı davranışları üzerinde kayda değer bir etkisi bulunmamaktadir.

Tablo 4’te öğretmenlerin kişilik özelliklerinin, duygusal emek düzeylerini yordayıp yordamadığının belirlenmesi amacı ile yapılan çoklu regresyon analizi sonuçlarına yer verilmiştir.

Tablo 4. Duygusal Emek Düreyinin Yordanmasına İliskin Regresyon Analiz̨i Sonuclarn

\begin{tabular}{|c|c|c|c|c|c|c|c|}
\hline Değişken & $B$ & Standart Hata & $\beta$ & $t$ & $p$ & $\begin{array}{c}\dot{I} \text { Ikili } \\
\boldsymbol{r}\end{array}$ & $\begin{array}{c}\text { Kismi } \\
r\end{array}$ \\
\hline Sabit & 2.41 & .20 & - & 11.90 & .00 & - & - \\
\hline 1. Dişa dönüklük & -.05 & .04 & -.06 & -1.13 & .26 & .17 & -.06 \\
\hline 2. $\quad$ Uyumluluk & .18 & .05 & .20 & 3.61 & .00 & .40 & .16 \\
\hline 3. Sorumluluk & .20 & .05 & .23 & 4.09 & .00 & .42 & .18 \\
\hline 4. $\quad$ Duygusal denge & .02 & .04 & .03 & 0.60 & .55 & .15 & .03 \\
\hline 5. $\quad$ Zekâ/hayal gücü & .17 & .05 & .18 & 3.20 & .00 & .37 & .14 \\
\hline $\mathrm{R}=.49 \quad \mathrm{R}^{2}=.24$ & & & $\mathrm{~F}_{(5-398)}$ & $555 \mathrm{p}=$ & & & \\
\hline
\end{tabular}

Tablo 4'e göre, duygusal emek ile kişilik özelliklerinin sorumluluk ( $\mathrm{r}=.42)$, zekâ/hayal gücü ( $\mathrm{r}=.37)$, uyumluluk ( $(\mathrm{r}=.40)$ boyutları arasında pozitif ve orta düzeyde ilişki; dişa dönüklük $(\mathrm{r}=.17)$, duygusal denge $(\mathrm{r}=.15)$ boyutları arasında ise pozitif ancak düşük düzeyde ilişki bulunmuştur. Diğer değişkenler kontrol edildiğinde ise zeka/hayal gücü $(\mathrm{r}=.14)$, sorumluluk $(\mathrm{r}=.18)$, uyumluluk $(\mathrm{r}=.16)$ ile duygusal emek arasinda pozitif ve düşük düzeyde bir ilişki; ancak dişa dönüklük ( $\mathrm{r}=-.06)$, duygusal denge $(\mathrm{r}=.03)$ değişkenleri ile istatistiksel olarak anlamlı bir ilişki bulunmamaktadır. Kişilik özelliklerinin boyutları tümü birlikte, öğretmenlerin duygusal emek düzeyleri ile orta düzeyde ve anlamlı bir ilişki vermektedir $(\mathrm{R}=.49$, $\mathrm{p}<.01)$.Standardize edilmiş regresyon katsayısına $(\beta)$ göre yordayıcı değişkenlerin öğretmenlerin duygusal emek düzeyleri üzerindeki göreli önem sırasi; sorumluluk, uyumluluk, zekâ/hayal gücü, duygusal denge ve dışa dönüklüktür. Regresyon katsayılarının anlamlılı̆̆na ilişkin t-testi sonuçları incelendiğinde sorumluluk, 
uyumluluk, zekâ/hayal gücü öğretmenlerin duygusal emeklerinin önemli yordayıcısıdır. Kişilik özelliklerinin boyutları tümü birlikte, öğretmenlerin duygusal emek düzeylerinin \% 24’ünü açıllamaktadır. Elde edilen bulgulara göre duygusal emeğin regresyon eşitliği şöyledir:

\section{Duygusal emek $=2.41-.05$ Dlşa dönüklïk +.18 Uyumluluk +.20 Sorumluluk +.02 Duygusal denge + .17 Zeka/ hayal gücü}

Regresyon eşitliğinde de görüldüğü gibi öğretmenlerin sorumluluk, uyumluluk ve zekâ/hayal gücü kişilik özelliği arttıkça duygusal emek davranışları da önemli düzeyde artmaktadır. Ancak dışa dönüklük ve duygusal denge kişilik özelliklerinin öğretmenlerin duygusal emek davranışları üzerinde kayda değer bir etkisi bulunmamaktadır.

Tablo 5'de öğretmenlerin kişilik özelliklerinin, genel mesleki profesyonellik düzeylerini yordayıp yordamadığının belirlenmesi amacı ile yapılan çoklu regresyon analizi sonuçlarına yer verilmiştir.

Tablo 5. Genel Mesleki Profesyonellik Düzeyinin Yordanmasina İlişkin Regresyon Analizi Sonucları

\begin{tabular}{|c|c|c|c|c|c|c|c|}
\hline Değişken & $B$ & Standart Hata & $\beta$ & $t$ & $p$ & $\begin{array}{c}\dot{I} k i l i \\
t\end{array}$ & $\begin{array}{c}\text { Kismi } \\
r\end{array}$ \\
\hline Sabit & 2.04 & .20 & - & 12.48 & .00 & - & - \\
\hline 1. Dişa dönüklük & .04 & .04 & .06 & 1.24 & .21 & .30 & .06 \\
\hline 2. $\quad$ Uyumluluk & .05 & .04 & .07 & 1.29 & .19 & .38 & .07 \\
\hline 3. $\quad$ Sorumluluk & .19 & .04 & .26 & 4.80 & .00 & .47 & .23 \\
\hline 4. Duygusal denge & .02 & .03 & .04 & 0.82 & .41 & .22 & .04 \\
\hline 5. $\quad$ Zekâ/hayal gücü & .24 & .04 & .28 & 5.45 & .00 & .48 & .26 \\
\hline $\mathrm{R}=.55 \quad \mathrm{R}^{2}=.31$ & & & $F_{(5-398)}=$ & $8 \mathrm{p}=$ & & & \\
\hline
\end{tabular}

Tablo 5'e göre, öğretmenlerin genel mesleki profesyonellikleri ile dişa dönüklük ( $\mathrm{r}=.30)$, uyumluluk $(\mathrm{r}=.38)$, sorumluluk $(\mathrm{r}=.47)$, zekâ/hayal gücü $(\mathrm{r}=.48)$ arasında pozitif ve orta düzeyde; duygusal denge $(\mathrm{r}=.22)$ arasında pozitif ve düşük düzeyde ilişki bulunmaktadır. Diğer değişkenler kontrol edildiğinde ise, öğretmenlerin mesleki profesyonelliği ile sorumluluk $(\mathrm{r}=.23)$ ve zekâ/hayal gücü(r=.26) arasinda pozitif ve düşük düzeyde ilişkiler bulunmuştur. Kişilik özelliklerinin boyutları tümü birlikte, öğretmenlerin genel mesleki profesyonellik düzeyleri ile orta düzeyde ve anlamlı bir ilişki vermektedir $(\mathrm{R}=.55, \mathrm{p}<.00)$. Standardize edilmiş regresyon katsayısına $(\beta)$ göre yordayıcı değişkenlerin öğretmenlerin genel mesleki profesyonellik düzeyleri üzerindeki göreli önem sırası; sorumluluk, zekâ/hayal gücü, uyumluluk, dışa dönüklük ve duygusal dengeliliktir. Regresyon katsayllarının anlamlılı̆ına ilişkin t-testi sonuçları incelendiğinde sorumluluk ve zekâ/hayal gücü öğretmenlerin genel mesleki profesyonelliklerinin önemli yordayıcısıdır. Kişilik özelliklerinin boyutları tümü birlikte, öğretmenlerin duygusal emek düzeylerinin \%31'ini açıklamaktadır. Elde edilen bulgulara göre genel mesleki profesyonelliğin regresyon eşitliği şöyledir:

\section{Genel Mesleki Profesyonellik $=2.04+.04$ Dısa dönüklïk +.05 Uyumluluk +.19 Sorumluluk +.02 Duygusal denge +.24 zekâl hayal gücü}

Regresyon eşitliğinde de görüldüğü gibi öğretmenlerin sorumluluk ve zekâ/hayal gücü kişilik özelliği arttıkça genel mesleki profesyonellik davranıșları da önemli düzeyde artmaktadır. Ancak dıșa dönüklük, uyumluluk ve duygusal denge kişilik özelliklerinin öğretmenlerin genel mesleki profesyonellik davranışları üzerinde kayda değer bir etkisi bulunmamaktadır.

\section{Tartışma, Sonuç ve Öneriler}

$\mathrm{Bu}$ araştırmada öğretmenlerin kişilik özellikleri ile mesleki profesyonellik düzeyleri arasındaki ilişki belirlenmeye çalışılmıştır. Öğretmenlerin mesleki profesyonellik düzeyleri yüksektir. Öğretmenler kendilerini mesleki duyarll1ık boyutunda, diğer boyutlara göre daha profesyonel görmektedir. Bu boyutu sırası ile duygusal emek, kuruma katkı ve kişisel gelişim boyutları izlemektedir. Altınkurt ve Ekinci (2016), Cansoy ve Parlar (2017), Çelik(2015) ve Kılınç’n (2014) öğretmenlerin mesleki profesyonelliği üzerine yaptığı araştırmada da öğretmenlerin mesleki profesyonelliği yüksek bulunmuş ve mesleki profesyonelliğin boyutlarına katılım düzeyleri de bu araştırma ile örtüşmektedir. Yorulmaz, Altınkurt ve Yılmaz'nn (2015) öğretmenler üzerinde gerçekleştirdikleri araştırmalarda da, öğretmenlerin mesleki profesyonelliği yüksek bulunmuş ve mesleki profesyonelliğin boyutlarına katılım düzeyleri de bu araştırmaya yakındır. Ancak 
Altınkurt ve Yılmaz'ın (2014) yaptığı araştırmada öğretmen profesyonelliği orta düzeyde bulunmuş; Bayhan (2011) ve Cerit'in (2012) yaptığı araştırmada ise öğretmenlerin mesleki profesyonellik düzeyleri düşük bulunmuştur. Mesleki duyarlılığın önemli davranışlarından birisi işini en iyi şekilde yapma gayretinde olmak, diğeri de mesleği ile ilgili meslektaşlarından geri bildirim almak olduğu söylenebilir. Katılımcılar öğretmenlik mesleğini en iyi biçimde yapmaya çalıştıklarını düşünmektedir. Yine katılımcllar meslekleri ile ilgili konularda geri bildirim almak istediklerini belirtmiştir. Bu sonuç, öğretmenlerin iletişim ve iş birliği içinde öğrenen bir okul kültürü oluşturması açısından önemlidir.

Mesleki profesyonelliğinin ikinci sırada yüksek olduğu duygusal emek boyutunda, öğretmenler mevcut duygu durumlarını, eğitim öğretim sürecine yansıtmamaya çalışmaktadırlar. Dolayısıyla öğretmenlerin, sınıf ortamında duygularını düzenleyebildikleri söylenebilir. Bu durum Bayhan'ın (2011) öğretmenlerin profesyonellik algılarının daha çok sınıf ve öğrenci alanlarında yüksek olduğunu saptamasında da öğretmenlerin sınıf ortamında gerçek duygularını gizleyerek mesleki profesyonellik düzeylerini yüksek tuttukları söylenebilir. Öğretmenlerin örgütsel amaçlara ve çalışma ortamına uygun davranışlar sergiledikleri söylenebilir. Bunun yanında öğretmenlerin profesyonellik davranışlanı, gerek sınıf içi gerek sınıf dışı öğretimi geliştirme çalışmalarını geliştirmeyi içermektedir (Carlgren, 1999). Öğretmenlik mesleğinin profesyonel olarak ortaya konulmasının temelinde öğrencilerin öğrenme niteliğine önem vermek gelmektedir (Phelps, 2003). Dolayısıyla da öğretmenlerin profesyonel davranışlarının öğrenci başarısına olumlu yansıyacağı söylenebilir (Hoque, Alam ve Abdullah, 2011; McDonald, Son, Hindman ve Morrison, 2005).

Öğretmenlerin, üçüncü sırada kuruma katk1 boyutuna "katıllyorum" ölçütünde yanıtlamalar1, kurumlarına katkılarının çok yüksek düzeyde olmadığ1 sonucunu göstermektedir. Katılımcılar kuruma katkı ile ilgili olarak, en çok bilgi ve iletişim teknolojilerini dersi geliştirmek için kullandıklarını, en az ise okuldaki sorunlar ile ilgili bilimsel araştırmalar yaptıklarını belirtmiştir. Bu sonuç, öğretmenlerin kişisel gelişim boyutunda en az katıldıkları maddenin, ögretmenlik alanı ile ilgili bilimsel toplantıları (kongre, sempozyum gibi) takip ettiklerini belirtmeleri ile birbirlerini desteklemektedir. Bu durum, Altınkurt ve Yllmaz'in (2014) araştırması ile örtüşmektedir. Ayrıca Yazıcı'nın (2020) okul müdürleri ile yaptığ araştırmada da benzer sonuç elde edilmiştir. Halbuki okul müdürleri öğretmenlerin bilimsel toplantılara (kongre, sempozyum gibi) katılmasını teşvik etmelidir. Çünkü öğretmen profesyonelliğini etkileyen aktörler arasından birisi de okul yönetimidir (Bayhan, 2011). Öğretmenler kendilerini geliştirmeye yönelik eğitim faaliyetlerine katılmaya isteksiz görünmektedir. Bunun nedenleri arasında Milli Eğitim Müdürlüğünün bilimsel toplant1, sempozyum, kongrelere katılım ile ilgili üniversitelerle yeterli iş birliği yapmamasının etkili olduğu; ayrıca öğretmenin aldığı eğitimler sonucunda somut bir kazanç sağlamadığı, çünkü bu etkinliklere katılımlarda öğretmenlere bir ödül verilmediği (Etkinliğe hizmet puanının verilmesi gibi) için bu etkinliklerin değerli bulunmadığı söylenebilir. Yine Fen Lisesi ve Anadolu Lisesi gibi proje okullarında çalışmak isteyen öğretmenlerin seçiminde kendini geliştirme koşulunun aranmaması; ayrıca bu etkinliklerin okul zamanı dışında planlaması ve öğretmenlerin de okul çıkışlarında katılmak istememeleri sayılabilir. Öğretmenler kişisel gelişimini sağladıkça okulda ve toplumda etkili olacaktır. Öğretmenlik sürekli gelişme halinde olunması gereken bir meslektir (Yilmaz ve Altınkurt, 2014).

Öğretmenlerin profesyonelliği konusunda yapılan araştırmaların çoğunda öğretmenlerin profesyonellik düzeylerinin yüksek olduğu bulunmuştur (Altınkurt ve Ekinci, 2016; Cansoy ve Parlar, 2017; Çelik, 2015; Kılınç, 2014). Bunun sonuçlarının, okulların işleyişi ve eğitimin niteliğine olumlu yansımalarının olması gerekmektedir. Ancak olumlu yansımaların uygulamada yeterince görülmemesi, öğretmenlerin profesyonel özelliklere sahip oldukları halde bu özellikleri işe koşmalarını engelleyici yapısal sorunlar olduğunu düşündürmektedir. Çünkü öğretmenlerin profesyonellik düzeyleriyle sergiledikleri profesyonellik davranışları uyuşmamaktadır. Bu yapısal sorunlar, Türk eğitim sisteminin aşırı merkeziyetçi yapıs1, eğitime erişimdeki eşitsizlikler, kalabalık sınıflar, ezberci eğitim, donanım ve fiziki alt yapı eksikliklerinden kaynaklanabilir (Yilmaz ve Altınkurt, 2011).

Öğretmenlerin mesleki profesyonellikleri, okul türü değişkenine göre anlamlı düzeyde farklılaşmamakta; cinsiyet, görev yapılan okul kademesi ve kıdem değişkenlerine göre ise farklılaşmaktadır. Cinsiyet değişkenine göre genel mesleki profesyonellik, kuruma katkı, kişisel gelişim puanlarında farklılık olmasa da, mesleki duyarlılık ve duygusal emek boyutlarında cinsiyete göre farklılık bulunmaktadır. Kadın öğretmenlerin hem mesleki duyarlılıkları hem de duygusal emekleri erkek öğretmenlerden daha yüksektir. Çelik ve Yılmaz (2015) ile Altınkurt ve Ekinci'nin (2016), öğretmenlerin mesleki profesyonelliği üzerine yaptığ1 araştırmalarda da kadın öğretmenlerin mesleki duyarlılı̆̆ ile duygusal emeklerinin erkek öğretmenlere göre yüksek düzeylerde bulması bu araştırma sonucu ile örtüşmektedir. 
Görev yapılan okul kademesi değişkenine göre sınıf öğretmenlerinin genel mesleki profesyonelliği, ortaokul ve lise öğretmenlerinden daha yüksektir. Benzer şekilde sınıf öğretmenlerinin kuruma katk1 düzeyi, ortaokul ve lise öğretmenlerinden daha yüksektir. Ayrıca ortaokul öğretmenlerinin de kuruma katkı düzeyi meslek lisesi öğretmenlerinden daha yüksektir. Mesleki profesyonelliğin duygusal emek boyutunda ise sınıf öğretmenleri, ortaokul ve meslek lisesi öğretmenlerinden daha yüksek düzeyde duygusal emek davranışları göstermektedir. Pearson ve Moomaw'n (2005) çalısmalarında lise öğretmenleri kendilerini daha fazla profesyonel olarak görmektedirler. Altınkurt ve Yılmaz'in (2014) çalışmalarında da öğretmenlerin profesyonellik düzeyleri kişisel gelişim, kuruma katkı ve duygusal emek boyutlarında okul türüne göre istatistiksel olarak anlamlı farklll1k göstermektedir. Kişisel gelişim boyutunda en yüksek ortalamaya lise öğretmenleri, kuruma katkı boyutunda en yüksek ortalamaya ilkokul öğretmenleri ve duygusal emek boyutunda ise en yüksek ortalamaya okulöncesi öğretmenleri sahiptir. İlkokul öğretmenlerinin kuruma katkı düzeylerinin yüksek olmasında zümre ve takım oyunu çalışmalarına, okul gelişim yönetim ekiplerine, sosyal, kültürel ve mesleki çalışmalara daha etkin katılmalarının etkisi olabilir. İlkokul öğretmenleri küçük yaş çocukları ile çalısmalarından dolayı velilerle iç içe bulunmaktadır. Bu durum, okula velilerin katkısını artırabilir. Ortaokulların meslek liselerine göre kuruma katkı düzeylerinin yüksek olmasina neden olarak, ortaokul öğretmenlerinin meslek lisesi öğretmenlerine göre iletişim ortamının daha yoğun olduğu okullarda çalısmaları, meslek lisesi öğretmenlerinin kültür dersi öğretmenleri ile iletişimlerinin düşük olmaları, kültür dersi öğretmenlerinin meslek dersi öğretmenleri ile ortak zümre çalışmaları içerisinde bulunamamaları söylenebilir. Duygusal emek boyunda ise ilkokul ögretmenlerinin mesleki profesyonellik düzeylerinin ortaokul ve meslek lisesi öğretmenlerine göre daha yüksek olmasının nedeni; meslektaşları ile daha çok iletişim içerisinde olmaları; öğrenci velilerine, çocuklarının gelişimi konusunda düzenli geri bildirimde bulunmalarından kaynaklı olduğu düşünülmektedir.

Kıdem değişkenine göre tüm boyutlarda en düşük mesleki profesyonelliğe 10 yıl ve altında kıdemi olan öğretmenler; en yüksek mesleki profesyonelliğe ise 21 yll ve üzerinde kıdemi olan öğretmenler sahiptir. 10 yıl ve az kıdeme sahip öğretmenlerin, kuruma katk1 ve duygusal emek düzeyleri diğer kıdem gruplarındaki öğretmenlerden; genel mesleki profesyonellik düzeyleri 21 yll ve üzeri kıdeme sahip ögretmenlerden daha düşüktür. Altınkurt ve Ekinci'nin (2016), öğretmenlerin mesleki profesyonelliği üzerine yaptığ1 araştırmada mesleki profesyonellik düzeyleri en düşük olan 11-20 yll kıdeme sahip öğretmenler olmuştur. Altınkurt ve Yılmaz'ın (2014) yaptığ1 araştırmada katılımciların, kuruma katkı, duygusal emek, kişisel gelişim, mesleki duyarllık, genel mesleki profesyonellik ile ilgili görüşleri kıdeme göre değiş̧memektedir. Bu araştırmada sınıf öğretmenlerinin mesleki profesyonelliği, ortaokul, lise ve meslek lisesi öğretmenlerinden daha yüksek bulunmuştur. Bayhan'n (2011) lise öğretmenleri, Çelik'in (2015) ilkokul, ortaokul öğretmenleri üzerinde yaptı̆̆ araştırmalarda, öğretmenlerin mesleki profesyonellikleri cinsiyet, yaş, medeni durum, görev yapılan okul türü ve kıdem değisskenine göre farklılaşmamakta, Çelik'in (2015) yaptığı araştırmada sadece branş değişsenine göre farklılaşmaktadır. Bu araştırmada da benzer şekilde, sınıf öğretmenlerinin mesleki profesyonelliği branş öğretmenlerinden daha yüksek bulunmuştur.

Öğretmenler sırası ile sorumluluk, uyumluluk, zekâ/hayal gücü, duygusal denge ve dışa dönüklük kişilik özelliklerini sergilemektedir. Tüm boyutlarda ortalamanın üzerinde kişilik özellikleri sergilemişlerdir. Yani öğretmenler önemli ölçüde olumlu kişilik özelliklerine sahip bireylerden oluşmaktadır. Bu bulgu ile hemen hemen benzer olan, Göksal'nn (2017) sınıf öğretmenleri üzerinde yaptığı araştırmada uyumluluk kişilik özelliğinin ön plana çıktığı, Aşkar'ın (2017) ilköğretim kurumları müdürlerinin kişilik özellikleri araştırmasında yine ilk sırada uyumluluk kişilik özelliği, en az sergiledikleri kişilik özelliği ise duygusal dengesizliktir. Kalafat (2012) tarafindan ortaöğretim öğretmenleri üzerinde yapılan araştırmada, öğretmenler kişilik boyutlarında kendilerini duygusal dengesizlik dışında ortalamanın üzerinde algılamışlardır. Kalaycı (2016) yaptığı araştırmada öğretmen adaylarının en çok dışa dönüklük, sonra sorumluluk ve zekâ/hayal gücü özelliklerine sahip oldukları ortaya çıkmıştır.

Öğretmenlerin dışa dönüklük, duygusal denge ve zekâ/hayal gücü kişilik özellikleri cinsiyete göre anlamlı düzeyde farklılaşmamaktadır. Ancak öğretmenlerin uyumluluk ve sorumluluk kişilik özellikleri cinsiyete göre farklılaşmaktadır. Kadın öğretmenlerin hem uyumluluk hem de sorumluluk kişilik özellikleri erkek öğretmenlerin uyumluluk ve sorumluluk kişilik özelliklerinden daha yüksektir. Bu bulgu alanyazındaki diğer araştırmalarla örtüşmektedir (Demirci, 2003). Ancak Birimoğlu'nun (2015) araştırmasında, uyumluluk, sorumluluk, zekâ/hayal gücü puanları erkeklerde daha yüksek iken duygusal dengesizlik puanları kadınlarda daha yüksek belirlenmiştir. Göksal'ın (2017) ve Kardaş'in (2018) yaptı̆g araştırmada sınıf öğretmenlerinin beş faktör kişilik özelliklerinin cinsiyet değişkenine göre anlamlı bir 
farklılık göstermediği belirlenmiştir. Kişilik özelliklerinin yalnızca cinsiyet tarafından açılanması doğru olmayabilir. Ancak öğretmenlerin uyumluluk ve sorumluluk kişilik özelliklerinin cinsiyet değişkenine göre farklılık göstermesinin temel nedenlerinden birinin, toplumsal cinsiyet kalıp yargıları olduğu söylenebilir. Ataerkil toplumlardaki cinsiyet kalıp yargıları, kadınların ve erkeklerin davranış biçimlerine dair kabul edilmiş fikirler olarak tanımlanabilir. Kadınla erkeğe biçilen farklı roller, küçük yaşlardan itibaren bireylerin hayatlarını şekillendirebilmektedir (TÜSİAD, 2018). Kadınların uyumluluk özelliklerinin erkeklerden anlamlı düzeyde yüksek olması, ataerkil toplumlarda, kadınların görece az söz hakkı olmasının doğal karşılanmasından kaynaklanabilir. Örneğin bu tür toplumlarda, kadınlara küçük yaşlardan itibaren öğretilen, "kadınlar her zaman uyumlu olmalıdır" ya da "kadınlar fazla ses çıkarmamalıdır" gibi kalıpsal yargılar, kadınların daha uyumlu bir kişilik özelliği sergilemelerinin nedeni olabilir.

Araştırmanın son amacı, öğretmenlerin kişilik özelliklerinin mesleki profesyonellik düzeylerini yordayıp yordamadığının belirlenmesidir. Bunun için regresyon analizinden yararlanılmıştır. Katılımcıların genel mesleki profesyonellikleri ile dışa dönüklük, uyumluluk, sorumluluk, zekâ/hayal gücü arasında pozitif ve orta; duygusal denge arasında pozitif ve düşük düzeyde ilişkiler bulunmaktadır. Diğer değişkenler kontrol edildiğinde ise öğretmenlerin mesleki profesyonelliği ile sorumluluk ve zekâ/hayal gücü arasinda pozitif ve düşük düzeyde ilişkiler bulunmuştur. Kişilik özelliklerinin boyutları tümü birlikte, öğretmenlerin genel mesleki profesyonellik düzeyleri ile orta düzeyde ve anlamlı bir ilişki vermektedir. Buna göre katılımcıların kişilik özellikleri olumlu yönde değiştikçe mesleki profesyonellik düzeyleri de yükselmektedir. Öğretmenlerin özellikle sorumluluk, zekâ/hayal gücü ve uyumluluklarının artması mesleki profesyonelliklerini artırıcı bir etkiye sahiptir. Çalışanların olumlu kişilik özelliklerine sahip olmasının, yaptığ1 işi profesyonelce yapmasını sağladığ1 söylenebilir. Koca’nın (2016) okul yöneticilerinin kişilik özellikleri ile mesleki doyum düzeyleri arasındaki ilişkiyi incelediği araştırmasında, kişilik özelliklerinin tüm boyutlarıyla mesleki doyum arasında anlamlı bir ilişki çıkmıştır. Olumlu kişilik özelliklerine (dışa dönüklük, zekâ/hayal gücü, uyumluluk, öz disiplin) sahip yöneticilerin mesleki doyumu yüksek iken olumsuz kişilik özelliğine (nörotiklik) sahip yöneticilerin mesleki doyumu düşüktür. Ercan'nn (2014), okul yöneticilerinin kişilik özellikleri ile karar verme becerileri arasındaki ilişkiyi inceleyen çalışmasına göre, ilkokul ve ortaokul yöneticilerinin kişilik özellikleri ile karar verme becerileri arasında olumlu yönde orta düzeyde bir ilisski saptanmiştır.

Öğretmenlerin kişilik özelliklerinin mesleki profesyonellik düzeylerini yordayıp yordamadığının belirlenmesine ilişkin yapılan regresyon analizi sonuçlarına göre sadece sorumluluk ve zekâ/hayal gücü kişilik özelliğinin öğretmenlerin mesleki profesyonelliklerinin önemli bir yordayıcısı olduğu belirlenmiştir. Öğretmenlerin zekâ/hayal gücü özellikleri eğitim örgütleri açısından önemlidir. Değişime ve gelişmeye istekli olan öğretmenler okulların değişiminde ve gelişiminde önemli rol oynamaktadır (Yılmaz, 2015, s. 788). Bu nedenle okullarda değişime yönelik alınacak kararlarda öğretmenleri karar alma sürecine katmak oldukça önemlidir. Ayrıca ögretmenlere yönelik, zekâ/hayal gücü ve sorumluluk kişilik özelliklerini geliştirici görüş ve politikalar geliştirilmelidir. Öğretmenlerin kişilik özellikleri mesleki profesyonellikleri üzerinde anlamlı düzeyde etkilidir. Kişilik özelliklerinin boyutları tümü birlikte, öğretmenlerin mesleki profesyonelliklerinin \%31'ini, açılamaktadır. Öğretmenlerin kişilik özellikleri olumlu yönde geliştikçe mesleki profesyonellikleri de artmaktadır. Alanyazında öğretmenlerin kişilik özellikleri ile mesleki profesyonellikleri arasındaki ilişkiyi belirleyen bir araştırmaya ulaşılamamışsı̆. Ancak mesleki profesyonelliğe benzer bileşenlerden oluşan; öğretmenlerin kişilik özelliklerinin öğretmen yeterliklerine etkisi ve öğretmenlerin kişilik özelliklerinin öğretmenlik mesleğine yönelik tutuma etkisi konularında yapılmış çalışmalar bulunmaktadır (Şenel, Demir, Sertelin, Kılıçaslan ve Köksal, 2004; Kalafat, 2012). Benzer bileşenlerle de olsa bu araştırmanın sonuçlarıyla örtüşen bulgular yer almaktadır. Bu araştırmalardan kişilik özellikleri ile öğretmen yeterlilikleri arasında orta düzeyde anlamlı ilişkiler bulunmakta ve en önemli yordayıcılarının da bu çalşsmayla benzer biçimde olan zekâ/hayal gücü ve sorumluluk boyutlarıdır. Sargın (2016) öğretmenlerin kişilik özellikleri, örgütsel sinizm ve iş doyumu arsasındaki ilişkiyi incelediği araştırma sonucunda dışa dönüklük kişilik özelliği ile örgütsel sinizmin bilişsel ve duyuşsal alt boyutlarının iş doyumunu anlamlı düzeyde yordadığını bulmuştur.

Araştırmada öğretmenlerin mesleki profesyonellik boyutlarının hepsini yordayan zekâ/hayal gücü ve sorumluluk kişilik özelliğidir. Bu nedenle öğretmenlere yönelik, mesleki profesyonelliğini etkileyen zekâ/hayal gücü ve sorumluluk kişilik özelliklerini geliştirici hizmet içi eğitim kursları düzenlenmelidir. Mesleki profesyonellik konusu ile ilgili okul iklimi, örgütsel adalet vb. değişkenleri içeren nicel çalışmalar yapılabilir. Öğretmenlerin profesyonellik algıları yüksek olduğu halde, bu özelliklerin uygulamaya ve 
sonuçlara yansıma düzeyi sınırlı görünmektedir. Bu durumun nedenlerini araştıran nitel çalışmalar yapılabilir.

\section{Etik Beyan}

"Öğretmenlerin Kişilik Özellikleri ile Mesleki Profesyonellikleri Arasındaki İlişki” başlıklı çalısmanın yazım sürecinde bilimsel kurallara, etik ve alıntı kurallarına uyulmuş; toplanan veriler üzerinde herhangi bir tahrifat yapılmamış ve bu çalışma herhangi başka bir akademik yayın ortamına değerlendirme için gönderilmemiştir. Gerekli olan etik kurallar açısından uygun olduğuna dair karar, Adnan Menderes Üniversitesi Eğitim Araştırmaları Etik Kurulunun 21.05.2021 tarih ve 12/1 sayı ile alınmıştır.

\section{Kaynakça}

Adıgüzel, O., Tanrıverdi, H. ve Sönmez-Özkan, D. (2011). Mesleki profesyonellik ve bir meslek mensupları olarak hemşireler örneği. Yönetim Bilimleri Dergisi, 9(2), 237-259.

Altinkurt, Y. ve Ekinci, C. E. (2016). Examining the relationships between occupational professionalism and organizational cynicism of teachers. Educational Process: International Journal, 5(3), 236-253.

Altınkurt, Y. ve Yılmaz, K. (2014). Öğretmenlerin mesleki profesyonelliği ile iş doyumları arasındaki ilişki. Sakarya University Journal of Education, 4(2), 57-71.

Anderson, M. (2012). The struggle for collective leadership: Thinking and practice in a multi-campus school setting. Educational Management Administration \& Leadership, 40(3), 328-342.

Aşkar, N. (2017). Anakara ili kamu temel eğitim okullar müdürlerinin sergilediklerri, özgeci davranışlar ile kişsilik öžellikleri arasindaki ilişski (Yüksek Lisans Tezi). Ankara Üniversitesi Sosyal Bilimler Enstitüsü, Ankara.

Basım, H. N. ve Beğenirbaş, M. (2012). Çalışma yaşamında duygusal emek: Bir ölçek uyarlama çalışması. Yönetim ve Ekonomi Dergisi, 19(1), 77-90.

Bayhan, G. (2011). Ögretmenlerin profesyonelliğinin incelenmesi (Doktora Tezi). Marmara Üniversitesi Eğitim Bilimleri Enstitüsü, İstanbul.

Birimoğlu, B. (2015). Simf ögretmenlerinin kişilik özellikleri ile is doyumlar arasindaki ilişkinin incelenmesi (Yüksek Lisans Tezi). Yeditepe Üniversitesi Eğitim Bilimleri Enstitüsü, İstanbul.

Boyt, T. E., Lusch, R. F. ve Naylor, G. (2001). The role of professionalism in determining job satisfaction in Professional services: A study of marketing researchers. Journal of Service Research, 3(4), 321-330.

Büyüköztürk, Ş. (2015). Sosyal bilimler için veri analizi el kitabı. Ankara: Pegem Akademi.

Cansoy, R. ve Parlar, H. (2017). Okul gelişiminin bir yordayıc1sı olarak öğretmen profesyonelizmi. Krrşehir Eğitim Fakïltesi Dergisi (KEFAD), 18(1), 269-289

Carlgren, I. (1999). Professionalism and teachers as designers. Journal of curriculum studies, 31(1), 43-56.

Cerit, Y. (2012). Okulun bürokratik yapısı ile sınıf öğretmenlerinin profesyonel davranışları arasındaki ilişki. Kuram ve Uygulamada Eg̈itim Yönetimi, 18(4), 497-521.

Çelik, M. ve Yllmaz, K. (2015). The relationship between teachers' occupational professionalism and burnout. Sakarya Üniversitesi Eğitim Fakültesi Dergisi, (30), 93-122.

Connor, C. M., Son, S. H., Hindman, A. H. ve Morrison, F. J. (2005). Teacher qualifications, classroom practices, family characteristics, and preschool experience: Complex effects on first graders' vocabulary and early reading outcomes. Journal of School Psychology, 43(4), 343-375.

Demirci, S. (2003). Öğretmenlerde bes faktör kişilik özellikleri ile iş doyumu arasindaki ilişkinin incelenmesi (Yüksek Lisans Tezi). Karadeniz Teknik Üniversitesi Sosyal Bilimler Enstitüsü, Trabzon.

Diefendorff, J. M., Croyle, M. H. ve Gosserand, R. H. (2005). The dimensionality and antecedents of emotion allabor strategies. Journal of Vocational Behavior, 66(2), 339-357.

Ercan, G. (2014). Illk ve ortaokul yöneticilerinin kişilik özellikleri ile karar verme becerileri arasindaki ilişki (Yüksek Lisans Tezi). Okan Üniversitesi, İstanbul.

Evans, L. (2008). Professionalism, professionality and the development of education professionals. British Journal of Educational Studies, 56(1), 20-38.

Evetts, J. (2011, October). Professionalism as an occupational value: The theoretical challenges in the sociology of professions. In Louvain Workshop Presentation, Louvain, Belgium.

Evetts, J. (2011). A new professionalism? Challenges and opportunities. Current Sociology, 59(4), 406-422. doi: $10.1177 / 0011392111402585$

Geist, J. (2003). Predictors of faculty trust in elementary schools: enabling bureaucracy, teacher professionalism, and academic press (Doctorate Thesis). Ohio StateUniversity.

Geist, J. ve Hoy, W. K. (2004). Cultivating a culture of trust: Enabling school structure, teacher professionalism and academic press. Leading \& Managing, 10(1), 1-17

Girgin, B. (2007). Beş faktör kişsilik modelinin ișyerinde duygusal tacize (mobbing) etkileri. Yayımlanmamış Yüksek Lisans Tezi, Dumlupinar Üniversitesi Sosyal Bilimler Enstitüsü, Kütahya.

Goldberg, L.R. (1990). An alternative description of personality": The big-five factor structure. Journal of Personality and Social Psychology, 59(6), 1216-1229. 
Göksal, M. (2017). Sinı ögretmenlerinin bes faktör kişilik öz̨ellikleri ile örgütsel vatandaşlı davranıslar arasindaki ilişkinin incelenmesi (Yüksek Lisans Tezi). Kahramanmaraş Sütçü İmam Üniversitesi Sosyal Bilimler Enstitüsü, Kahramanmaraş.

Göl, L. ve Yıldırım, A. (2015). Illkokul ve ortaokul ögrretmenlerinin kişilik özellikleri ile iş doyumlar arasmdaki ilişki. Yayımlanmamış Yüksek Lisans Tezi, Necmettin Erbakan Üniversitesi, Konya.

Hargreaves, D. H. (1994). The new professionalism: The synthesis of professional and institutional development. Teaching and teacher education, 10(4), 423-438.

Hogan, R. (2009). Kisilike ve kurumlarn kaderi (Çev: S. Y. Kölay). İstanbul: Remzi Kitabevi.

Hoque, K. E., Alam, G. M. ve Abdullah, A. G. K. (2011). Impact of teachers' Professional development on school improvement-an analysis at Bangladesh standpoint. Asia Pacific Education Review, 12(3), 337-348.

Hoy, W. K., Hannum, J. ve Tschannen-Moran, M. (1998). Organizational climate and student achievement: A parsimonious and longitudinal view. Journal of School Leadership, 8(4), 336-359.

Hoy, W.K. \& Sabo, D.J. (1998). Quality middle schools: Open and healthy. Thousand Oaks, CA: Corwin Pres.

Isenbarger, L. ve Zembylas, M. (2006). The emotional labour of caring in teaching. Teaching and Teacher Education, 22(1), 120-134.

Kalafat, S. (2012). Lise öğretmenleri kişilik özelliklerinin öğretmen yeterliliklerine etkisi. Yüksekögretim ve Bilim Dergisi, 2(3), 193-200

Kalayc1, Y. (2016). Öğgretmen adaylarmm kişilike öz̧ellikleri ile çatışma yönetim yaklaşımlar arasındaki ilişki (Yüksek Lisans Tezi). Anadolu Üniversitesi, Sosyal Bilimler Enstitüsü, Eskişehir.

Kardaş, S. (2018). Beş faktör kişilik özelliklerinin iş tatmini üzerindeki etkisi. Yayınlanmamış Yüksek Lisans Tezi, İstanbul Ticaret Üniversitesi, İstanbul.

Kılınç, A. Ç. (2014). Öğretmen profesyonelizminin bir yordayıcısı olarak okul kültürü. Eğitim ve Bilim, 39(174), 105118.

Koca, E. (2016). Okul yöneticilerinin kişilik özellikleri ile mesleki doyum düzeyleri arasındaki ilişki (Yüksek Lisans Tezi). Marmara Üniversitesi, Sosyal Bilimler Enstitüsü, İstanbul.

Larson, M. S. (1977). The rise of professionalism: A sociological analysis. California: University of California Press.

McMahon, E. and Hoy, W. K. (2009). Professionalism in teaching: Toward a structural theory of professionalism. In W. K. Hoy and M. Di Paola (Eds.). Studies in school improvement. Greenwich, CN: Information Age, 205-230.

Murphy, G. A. ve Calway, B. A. (2008). Professional development for professionals: beyond sufficiency learning. Australian Journal of Adult Learning, 48(3), 424-444.

Ones, D.S., Viswesvaran, C. ve Dilchert, S. (2005). Personality at work: raising awareness and correcting misconceptions, Human Performance, 18(4), 389-404.

Pearson, L. C. ve Moomaw, W. (2005). The relationship between teacher autonomy and stress, work satisfaction, empowerment, and professionalism. Educational Research Quarterly, 29(1), 38-54.

Phelps, P. H. (2003). Teacher professionalism. Kappa Delta Pi Record, 40(1), 7-11.

Sargin, A. (2016). Ögrretmenlerin kişilik özellikleri, örgütsel sinizm, iş doyumu arasındaki ilişki (Yüksek Lisans Tezi). Karadeniz Teknik Ünivesitesi, Sosyal Bilimler Enstitüsü, Trabzon.

Sayg1l, G. (2010). Öğretmenlerin kişilik özellikleri ile okul iklimi algilan arasindaki iliş̧kinin incelenmesi (Istanbul İli Sancaktepe İlcesi örneği) (Yüksek Lisans Tezi). Yeditepe Üniversitesi, İstanbul.

Somer, O. ve Goldberg, L. R. (1999). Personality processes and individual differences. Journal of Personality and Social Psychology, 76(3), 431-450.

Şenel, H. G., Demir, İ., Sertelin, Ç., Kılıçaslan, A. ve Köksal, A. (2004). Öğretmenlik mesleğine yönelik tutum ve kişilik özellikleri arasındaki ilişki. Ë̆gitim Araştırmalar, 15(4), 99-109.

Tatar, A. (2017). Büyük beş kişilik testinin Türkçe'ye çevirisi ve beş faktör kişilik envanteri kısa formu ile karşılaştır1lması. Anadolu Psikiyatri Dergisi, 18(1), 51-61.

Toh, K. A., Diong, C. H., Boo, H. K. ve Chia, S. K. (1996). Determinants of teacher professionalism. British Journal of in-Service Education, 22(2), 231-244.

Tschannen-Moran, M., Parish, J. ve Dipaola, M. (2006). School climate: The inter play between inter personal relationships and student achievement. Journal of School Leadership, 16(4), 386-415.

Tschannen-Moran, M. (2009). Fostering teacher professionalism in schools: The role of leadership orientation and trust. Educational Administration Quarterly, 45(2), 217-247.

Tukonic, S., ve Harwood, D. (2015). The glass ceiling effect: Mediating influences on early years educators' sense of professionalism. Journal of the Canadian Association for Young Children, 40(1), 36-54.

TÜSİAD. (2018). İletişimde toplumsal cinsiyet eşitsiz̨liği rehberi. İstanbul: Sis Matbacilık.

Yazıc1, A. Ş. (2020). Okul müdürlerinin mesleki profesyonellikleri ile yaşam boyu ögrenme eğilimleri: Bir karma yöntem çalşsması (Muğla ili örneği) (Doktora Tezi). Adnan Menderes Üniversitesi, Aydın.

Yılmaz, K. ve Altınkurt, Y. (2011). Öğretmen adaylarının Türk eğitim sisteminin sorunlarına ilişkin görüşleri. Uluslararası İnsan Bilimleri Dergisi, 8(1), 942-973.

Yilmaz, K. (2014). The relationship between the teachers' personality characteristics and burnout levels. The Anthropologist, 18(3), 783-792.

Yılmaz, K. ve Altınkurt, Y. (2014). Öğretmenlerin mesleki profesyonelliği ölçeği geçerlik ve güvenirlik çalışması. Uluslararası Insan Bilimleri Dergisi, 11(2), 332-345. 
Yılmaz, K. ve Altınkurt, Y. (2015). Öğretmenlerin mesleki profesyonellikleri ile iş-yaşam dengeleri arasındaki ilişki. Eğitim Bilimleri ve Uygulama Dergisi, 14(28), 105-128

Yorulmaz, Y., Altınkurt, Y. ve Yilmaz, K. (2015). The relationship between teachers' occupational professionalism and organizational alienation. Educational Process: International Journal, 4(1-2), 31-44.

\section{EXTENDED ABSTRACT}

Like any profession, the teaching profession has its own unique characteristics. These characteristics can be said to actually define the profession. As professions change and develop these characteristics, they become more professional. Pre-service training of teachers, existence of criteria and processes for appointment, the profession's being divided into branches, developing standards in the practices of the profession, teachers' earning money in return for their work can be counted as characteristics indicating its having completed its professionalization or its still being in the process of professionalization. Along with these characteristics of the profession, organizations continue to develop by becoming more complex in today's changing and developing conditions. While professions continue this development, the quality of the work done becomes important. The nature of the job is related to the intrinsic motivation and internal control of the people doing the job, their wishes and curiosity. These indicators can also be called the individual professionalism of the people. While teachers create their organizational professionalism with the characteristics of their profession, they also create their individual professionalism with their success in education. The replacement of individual professionalism with organizational professionalism constitutes occupational professionalism (Evets, 2011; Altınkurt, \& Yilmaz, 2014).

Employees' intrinsic motivation and internal locus of control are as important as structural factors in occupational professionalism (Boyt, Lusch, \& Naylor, 2001) because people's action is the result of their own wishes. For example, people with internal locus of control think that they are responsible for their own lives and act accordingly (Yllmaz, \& Altınkurt, 2014, p. 333). Similarly, Larson (p. 29, 1977) explains occupational professionalism on the basis of intrinsic value. Professionalism is defined as the individual's professional standing having ideological, intellectual, behavioural and epistemological bases (Evans, 2008, p. 24, 26). This individual standing creates personal differences in the way people play their roles within the organization (Hogan, 2019, p. 23) because personal differences are mostly caused by personality traits of individuals. In this regard, it is aimed in the current study to reveal the relationship between teachers' personality traits and their occupational professionalism.

Personality is a collection of consistently displayed traits that are unique to the individual and distinguish him/her from other individuals. Personality can be seen as a collection of traits that represent who individuals are (Yilmaz, 2014, p. 783). Ones, Viswesvaran, and Dilchert (2005) define personal traits as a set of individual traits that suggest that people consistently differ in terms of their basic tendencies to think, feel and act in certain ways. The traits approach is the approach most interested in personality. In this approach, personality is basically defined in terms of five general dimensions. These are extraversion, adaptability, responsibility, emotional balance, intelligence / imagination.

The purpose of the current study is to examine teachers' personality traits and occupational professionalism separately and comparatively. In line with this general purpose, the research problem of the study is worded as follows: "Is there is a significant correlation between personality traits of teachers and their occupational professionalism?"

The study was designed in the survey model. The population of the study is comprised of 12,181 teachers while the sampling consists of 429 teachers. The disproportionate cluster sampling technique was used to determine the sample. The Teachers' Occupational Professionalism Scale and Personality Traits Scale were used as the data collection tools in the study. The Teachers' Occupational Professionalism Scale was developed by Yulmaz and Altnkurt (2014). The Five Factor Personality Scale developed by Goldberg (1992) was adapted into Turkish by Tatar (2017). In the current study, descriptive statistics, ttest for binary comparisons, one-way analysis of variance (ANOVA) for comparisons with three or more dimensions were used in the study. Pearson correlation analysis was used for the relationship between variables. In addition, regression analysis was conducted to determine the extent to which teachers' personality traits predict their occupational professionalism.

The dominant personality traits of the teachers participating in the study are responsibility, adaptability, intelligence / imagination, emotional balance and extraversion. The general occupational professionalism level of the teachers participating in the study is high. The highest level of occupational 
professionalism of the teachers was found in the dimension of professional sensitivity, followed by the dimensions of emotional effort, contribution to the organization and personal development. All the dimensions of personality traits together are moderately and significantly correlated with the general occupational professionalism level of the teachers. According to the results of the regression analysis, it was determined that only responsibility and intelligence / imagination are important predictors of the teachers' occupational professionalism. Teachers willing to change and develop play an important role in the change and development of schools (Yllmaz, 2015, p. 788). For this reason, it is very important to include teachers in the decision-making process when making decisions regarding changes in schools. In addition, opinions and policies that improve intelligence / imagination and responsibility personality traits should be developed for teachers. The dimensions of personality traits together explain $31 \%$ of the teachers' occupational professionalism. As the personality traits of teachers improve, their occupational professionalism also increases.

In the current study, it is the intelligence / imagination and responsibility personality traits that predict all the occupational professionalism dimensions of the teachers. For this reason, in-service training courses that develop intelligence / imagination and responsibility personality traits affecting the occupational professionalism of teachers should be organized. Studies involving variables such as school climate and organizational justice related to occupational professionalism can be conducted. Since the research is limited to Muğla province, similar research can be done in different provinces. 